Sains Malaysiana 49(9)(2020): 2159-2168

http://dx.doi.org/10.17576/jsm-2020-4909-14

\title{
Antidiabetes Activity of Herbal Product Containing Phyllanthus niruri and Zingiber americans
}

(Aktiviti Antidiabetes Produk Herba yang Mengandungi Phyllanthus niruri dan Zingiber americans)

ELFAHMI*, I KetUt AdNYANA, IKA Fitria \& TAUfiK TAUfikurahman

\begin{abstract}
The diabetes mellitus is one of the chronic diseases that has high prevalence rates in the world. It is defined as a state of hyperglycemia which usually accompanied by increasing blood glucose level. The combination of Phyllanthus niruri herbs and Zingiber americans rhizome has been produced as herbal medicine for the treatment of diabetes. The efficacy of combination of these plants is still based on empirical data. This research aimed to prove the antidiabetes activity of herbal medicine product containing P. niruri and Z. americans in vivo. Antidiabetes activity was tested using oral glucose tolerance and alloxan induced methods. The blood glucose levels were measured in each experiment. In addition, the plasma triglyceride and total cholesterol levels were also measured. The results showed that the decrease of blood glucose levels on oral glucose tolerance method were 40.98, 44.84, and 47.02\% at doses of 90, 135, and 203 $\mathrm{mg} / \mathrm{kg} \mathrm{BW}$, respectively $(p<0.05)$ compared to control. While the decrease in blood glucose levels in alloxan induced method were 33.05, 38.82, and 41.79\% at dose 90, 135, and $203 \mathrm{mg} / \mathrm{kg} \mathrm{BW}$, respectively $(p<0.05)$ compared to control. The extract of dose $203 \mathrm{mg} / \mathrm{kg} \mathrm{BW}$ appeared to be the most potent to decrease blood glucose levels in both methods, but did not show suppression activity of triglycerides and total cholesterol plasma. Suppression activities of serum triglycerides and total cholesterol were shown after treatment with the extract dose 90 and $135 \mathrm{mg} / \mathrm{kg} \mathrm{BW}$, which were significantly different to control $(p<0.05)$. The herbal product contains flavonoid, phenol and tannin, which total of each were $0.15,0.16$, and $1.85 \% \mathrm{w} / \mathrm{w}$, respectively.
\end{abstract}

Keywords: Diabetes; herbal medicines; jamu; Phyllanthus niruri; Zingiber americans

ABSTRAK

Penyakit kencing manis ialah salah satu penyakit kronikyang umum di dunia. Penyakit ini didefinisikan sebagai keadaan hiperglikemik yang diikuti dengan tingginya kadar gula dalam darah. Kombinasi tanaman herba Phyllanthud niruri dan Zingiber americans telah dijadikan sebagai produk ubat herba untuk mengubati penyakit diabetes. Kesan daripada gabungan dua tanaman ini masih berdasarkan kepada data empirik. Kajian ini dijalankan untuk membuktikan khasiat anti-diabetes daripada salah satu produk ubatan herba yang mengandungi P. niruri dan Z. americans secara in vivo. Kajian ke atas anti-diabetes ini dijalankan menggunakan kaedah induksi aloksan. Kandungan gula dalam darah untuk setiap percubaan dihitung. Selain itu, kadar trigliserids dan kolestrol juga diukur. Hasil menunjukkan bahawa kadar gula dalam darah dapat diturunkan dengan kaedah toleransi glukosa sebanyak 40.98, 44.84 dan 47.02\% dengan dos 90, 135 dan $203 \mathrm{mg} / \mathrm{kg} \mathrm{BW}(p<0.05)$ berbanding kawalan. Penurunan dengan kaedah induksi aloksan pula adalah 33.05, 38.82 dan 42.79\% pada dos 90, 135 dan $203 \mathrm{mg} / \mathrm{kg} \mathrm{BW}(p<0.05)$ berbanding kawalan. Ekstrak yang mengandungi dos $203 \mathrm{mg} / \mathrm{kg} \mathrm{BW}$ menunjukkan penurunan kadar gula dalam darah paling tinggi dalam keduadua kaedah yang digunakan, namun tidak menunjukkan aktiviti penindasan trigliserids dan jumlah plasma kolestrol. Aktiviti penindasan serum trigliserids dan jumlah kolesterol dilihat selepas rawatan dengan ekstrak dos 90 dan 135 $m g / k g B W$, berbanding kawalan ( $p<0.05)$. Produk herba ini mengandungi flavonoid, fenol dan tanin dengan jumlah sebanyak $0.15,0.16$ dan $1.85 \% \mathrm{w} / \mathrm{w}$.

Kata kunci: Jamu; kencing manis; Phyllanthus niruri; ubat herba; Zingiber americans

\section{INTRODUCTION}

Herbal medicines have been used by community to treat diseases and to maintain health since long ago. They have been developed from traditional way into modern processing and produced as herbal medicines by household into big industries. The development of herbal medicines product should be followed by the good quality production to prove the efficacy, the quality and standardization (Elfahmi et al. 2014). Herbal medicine produced by small enterprise has been marketed for antidiabetes. Diabetes 
melitus (DM) is a chronical disease with high prevalence in the world. In Indonesia, the diabetes patient tends to rise every year where in 2000 , there were 8.4 million people with diabetes and is predicted to rise around 21.3 million in 2030 (Wild et al. 2004). In 2019, the diabetes patients reach 463 million people (IDF 2019; WHO 2019). This disease is defined as hyperglycaemic with abnormalities of carbohydrate, protein, and lipid metabolism as well as abnormality of production and activity of insulin (Shan et al. 2006). The use of antidiabetes drugs tend to increase since the rising of diabetes cases. Many medicinal plants have been reported to have antidiabetes activity. Meniran or Dukung anak (Phyllanthus niruri L.) belonging to family Phyllanthaceae is a medicinal plant that has been used traditionally for treat diabetes (Calixto et al. 1998; Nwanjo et al. 2017). Empirically, this plant has been also used mostly for the remedy of fever, inflammation, malaria, lithiasis, gonorrhea, hepatitis, genitourinary, hypertension, cancer, skin, digestive, hepatic, and respiratory disorders (Jantan et al. 2019; Sarin et al. 2014). The pharmacological activities of this plant were intensively studied to prove its traditional use. Methanol extract of this plant showed the highest inhibitory effect against non-alcohol-fatty liver disease through reduction of several parameters such as hepatomegaly, visceral fat weight, prevented fibrosis, serum total cholesterol, low-density lipoprotein, and free fatty acids. It also inhibited the activity of enzymes related, to diabetes such as $\alpha$-glucosidase and pancreatic lipase enzymes (Al Zarzour et al. 2018, 2017). The methanol extract was reported to have anti-inflammatory activity and protect the ulcer through the regeneration of mucosal layer and substantial prevention of the formation of hemorrhage and edema (Mostofa et al. 2017). While the aqueous extract reduced the amount of lipid peroxidation product, and inhibited the enzymes related to the oxidative stress such as superoxide dismutase, catalase, and glutathione peroxidase in the kidney of diabetic rats (Giribabu et al. 2018). P. niruri has been reported to be potential developed as an anticancer since it inhibits cancer cell in vitro (Junior et al. 2012; Tang 2013; Zheng et al. 2016). In addition, the pharmacological effects of this plant as anti-parasite, anti-bacterial, anti-virus, cardiovascular protective, antioxidant, anti-aging and skin protecting have been also reported (Nisar et al. 2018; Sarin et al. 2014). Only few reports have been published on the antidiabetes activity of $P$. niruri in vivo (Bavarva $\&$ Narasimhacharya 2007). One of them reported that $P$. niruri extract decreased the serum glucose level of type 2 diabetes in Sprague-Dawley rats induced by streptozotocin (Mediani et al. 2016). Some chemical compounds from several secondary metabolites group have been isolated from this plant. It contains flavonoid group such as quercetin and rutin; alkaloids: allonorsecurinine, ent- norsecurinine, and nirurine; phenolic such as gallotannins corilagin and geraniin. The most abundant compound found in P. niruri is lignin group such as phyllantin, hypophillantin, cubebin, nirtetarlin, and tetralin (Jantan et al. 2019; Nisar 2018). Two lignan compounds have been found in cell suspension cultures of $P$. niruri that has not been found in the original plant (Elfahmi et al. 2014). Lempuyang pahit (Zingiber americans B1.) belong to family Zingiberaceae has been also used traditionally for the treatment of diabetes, stomach disease, and reducing blood level (Al-Amin et al. 2006; Sukari et al. 2008). The scientific reports on pharmacology study of this plants are still limited. Combination of meniran herb and lempuyang pahit rhizome has been produced and marketed as herbal medicine belong to jamu by a small enterprise for the treatment of diabetes. Nowadays, the evidence for the efficacy of this herbal medicine product is still based on empirical data. Therefore, there is no scientific evidence for the combination of two plants for the treatment of diabetes. The research was conducted to prove the claimed efficacy as antidiabetes. Antidiabes activity was studied using glucose tolerance and alloxan induced methods. In addition, the phytochemical study was also conducted for herbal medicine product to know the phytochemical profile for standardization.

\section{MATERIALS AND METHODS}

\section{PLANT AND CHEMICALS}

The sample used was herbal medicine product containing extract of Phyllanthus niruri L. and Zingiber americans BI, metformin (PT. Kalbe Farma, Jakarta, Indonesia), alloxan monohydrate (Sigma Aldrich, Darmstaad, Germany), amyl alcohol, magnesium, chloroform, ammonia 25\%, Dragendorff, and Mayer reagent, $\mathrm{FeCl}_{3}$, CMC-Na, $\mathrm{Al}_{2} \mathrm{Cl}_{3}$, sodium acetate, sodium bicarbonate, methanol, ethanol, toluene, and acetone (all reagent and solvents were analytical grades).

\section{PHYTOCHEMICAL SCREENING AND STANDARDIZATION}

Phytochemical screening was carried out to identify the secondary metabolites groups in the extract of herbal medicines product which contain $P$. niruri and $Z$. americans. The secondary metabolites measured were alkaloid, flavonoid, tannin, saponin, quinone, and steroid/triterpenoid. Quantitative measurement of total flavonoid was done by colorimetric method (Chang 2002). While the total phenolic compound was measured by Spectrophotometer UV. Several parameters for standardization such as total ash content, water content, water and ethanol extractable matter and TLC profile were measured according to Indonesian Herbal Pharmacopoea (IMH 2008). 


\section{ANTIDIABETES ACTIVITY USING GLUCOSE TOLERANCE METHOD}

Male mouse Swiss Webster age 2-3 months were used as animal model and divided into several groups. Animals were fed and adapted at the lab according to standard procedures. Samples were prepared with dissolving of the extract from capsule of herbal medicines product with tragacanth $0.5 \%$. Antidiabes activity was carried out using glucose tolerance method and alloxan induced method (Shan et al. 2006). For glucose tolerance method, mouse was fasted for 10-12 $\mathrm{h}$ before induction, then randomly divided into 5 groups consist 5 mice of each group. Fasting blood glucose level were measured $\left(\mathrm{T}_{0}\right)$. Control group was given $\mathrm{CMC} \mathrm{Na} 0.5 \%$, standard group was given metformin $195 \mathrm{mg} / \mathrm{kg} \mathrm{bb}$, treated groups were given the extract with dose 90,135 , and $203 \mathrm{mg} / \mathrm{kg}$ $\mathrm{BW}$. Thirty minutes after treatment, each group was given glucose solution with concentration $3 \mathrm{~g} / \mathrm{kg}$ BW per oral. Blood glucose levels were measured at 30,60, 90, and 120 min after glucose treatment.

\section{ANTIDIABETES ACTIVITY USING ALLOXAN INDUCED METHOD}

For alloxan induced method, mouse was fasted for 10 $12 \mathrm{~h}$. Before induction, fasting blood glucose levels were measured so called $\mathrm{H}_{0}$. Mouse were induced with alloxan dose $57 \mathrm{mg} / \mathrm{kg} \mathrm{BW}$ i.v. On day 7 after induction $\left(\mathrm{H}_{7}\right)$, blood glucose levels were measured. Samples were given to mouse with the blood glucose level higher than $225 \mathrm{mg} / \mathrm{dL}$. Diabetic mouse was randomly divided into five groups. Control group was given CMC-Na $0.5 \%$. Standard group was given metformin $195 \mathrm{mg} / \mathrm{kg} \mathrm{BW}$. Three treated groups were given extract sample with three different concentrations which were 90, 135, and $203 \mathrm{mg} /$ $\mathrm{kg} \mathrm{BW}$, respectively. Prior to treatment, samples were suspended in CMC-Na $0.5 \%$ solution. The treatment was done during 21 days. Blood glucose levels of all mouse groups were measured on day 8, 10, 14, 21 and 28 using glucose strip test and glucometer GlucoDr ${ }^{\mathrm{TM}}$. Data were statistically analyzed using ANOVA method.

\section{CHOLESTEROL AND TRIGLYCERIDE ANALYSIS}

In addition, total cholesterol and triglyceride levels were measured before induction $\left(\mathrm{H}_{0}\right)$, and after induction $\left(\mathrm{H}_{7}\right)$. Cholesterol total was measured using enzymatic colorimeter method. Three type of samples were prepared, which were blank, standard, and treated solution. Blank solution consists of total cholesterol reagent. Standard solution consists of $1 \mathrm{~mL}$ of reagent and $10 \mu \mathrm{L}$ of standard solution. Treated samples consist of $1 \mathrm{~mL}$ reagent and $10 \mu \mathrm{L}$ of tested animal serum. All solution was incubated at room temperature $\left(18-30{ }^{\circ} \mathrm{C}\right)$. Absorbance of all solutions were measured at wavelength of 546 $\mathrm{nm}$. Total triglyceride levels were measured using GPO enzymatic colorimeter method. Three types of solution as mentioned with different reagent were prepared, followed by the same procedure with determination of total cholesterol level.

\section{RESULTS AND DISCUSSION}

The herbal product which contains $P$. niruri and $Z$. americans produced by small enterprise was registered in Indonesian FDA. This herbal medicine product was classified as jamu or traditional medicine since the efficacy claim is based on empirical data. There is no scientific study to prove the claim yet. Through the community services supported by Indonesian Ministry of Higher Education and with collaboration with the producer, the in vivo antidiabtes study of the product was carried out. Phytochemical study and quantitative measurement of the extract sample, showed that the product contain flavonoid, phenol, and tannin, with total of each were $0.15,0.16$, and

TABLE 1. Standardization parameter of extract sample was compared to the standard according to Indonesian herbal pharmacopoeia (FHI)

\begin{tabular}{|c|c|c|}
\hline Parameter & Extract $(\%)$ & $\begin{array}{c}\text { Phyllanthus niruri extract } \\
\text { (FHI in } \%)\end{array}$ \\
\hline Water content & $3.98^{*}$ & $<17$ \\
\hline Total ash content & 1.04 & $<3.5$ \\
\hline Lost on drying & 6.15 & - \\
\hline Water extractable matter & 67.58 & - \\
\hline Ethanol extractable matter & 6.69 & - \\
\hline Total flavonoid & 0.15 & 3.2 \\
\hline Total phenol content & 0.16 & - \\
\hline Total tannin content & 1.85 & - \\
\hline
\end{tabular}


$1.85 \% \mathrm{w} / \mathrm{w}$, respectively. For standardization process, some parameters are shown in Table 1, indicated that the extract sample fulfilled the standard of Indonesia herbal pharmacopoeia for water and ash contents, however, the flavonoid total was below standard. Others parameter were not included in FHI for extract monograph, they are included in the crude dried plant material. These parameters indicated the quality of extract (IMH 2008).

Further analysis of chemical components of extract sample using thin layer chromatography (TLC) showed the chromatogram profile as Figure 1. Almost all bands showed by the $P$. niruri and $Z$. americans were exist in the extract sample. At least 5 of 9 bands which was shown in extract samples have similar Rf value as shown by $P$. niruri extract. While 4 other bands of sample extract have similar Rf value as shown by $Z$. officinale extract. These results confirmed that the herbal medicine product contains these two plant extracts. In addition, after visualization using citroborate, a specific spray reagent for flavonoid, also confirmed the standard of extract sample. One of the bands was a quercetin compound.

Antidiabes test using glucose tolerance method was done for normal male mouse with blood glucose level ranging 96-107 $\mathrm{mg} / \mathrm{dL}$. The value complies with the value of normal value published before which is below $199 \mathrm{mg} / \mathrm{dL}$ (Fajardo et al. 2014). The study was carried out to determine whether the extract sample inhibit the increase of blood glucose level and recover it into normal after the increase caused by glucose induction. The blood glucose level increased for all animal groups, $30 \mathrm{~min}$ after glucose intake $\left(\mathrm{T}_{60}\right)$, The treated groups showed the lower increase of blood glucose level compared to control group. After $\mathrm{T}_{60}$, the reducing of blood glucose level was significant. Sixty minutes after treatment $\left(\mathrm{T}_{90}\right)$, there was significant different of blood glucose level for control, the samples of dose 90, 135, and $203 \mathrm{mg} / \mathrm{kgBW}$ compared to $\mathrm{T}_{60}$ (Figure 2). Measurement after $\mathrm{T}_{60}$, each treated group showed the reducing of blood glucose level and significantly different to control group $(\mathrm{p}<0.05)$. Metformin as a standard showed the highest reducing of glucose blood level. Metformin reduced the blood glucose level with the mechanism to increase the insulin sensitivity in liver and peripheral tissue. It reduces the production of glucose by liver and increase the glucose intake by peripheral tissue (AHFS 2008). The different of reducing level in $\mathrm{T}_{60}-\mathrm{T}_{120}$ and $\mathrm{T}_{60}-\mathrm{T}_{150}$ for treated groups is not significant to standard metformin group. The reducing of blood glucose levels after 120 min treatment with dose 90 , 135 , and $203 \mathrm{mg} / \mathrm{kg} \mathrm{BW}$ were 40.98, 44.84, and 47.02\%, respectively. The group treated with dose $203 \mathrm{mg} / \mathrm{kg} \mathrm{BW}$ gave the reducing level similar to standard metformin and appear as the dose with highest level of reducing (Figure 3 ). It assumed that the sample was not only able to suppress the increase of blood glucose level, but also to reduce it.
For alloxan induced method, mouse was induced using alloxan monohydrate. Alloxan was given with dose $57 \mathrm{mg} / \mathrm{kg}$ BW i.v. Alloxan has the diabetogenic effect to $\beta$-pancreas cell through some mechanism such as inhibition of glucokinase activity, production of free radical and disturb the homeostasis of intracellular calcium ion (Szkudelski 2001). The time needed to provide diabetic animal with stable blood glucose level above $225 \mathrm{mg}$ / dL was normally reached after 3-7 days. On day 7 after induction, blood glucose level of mouse was ranging 312$455 \mathrm{mg} / \mathrm{dL}$. This range was big enough, since the alloxan effect is influenced by nutrition status and age of animal model (Szkudelski 2001). Diabetic animal model for this study was moderate-high model. Diabetic condition was provided due to the alloxan activity toward $\beta$-pancreas caused insulin deficiency. Profile of glucose level for day 7-28 is similar between standard and treated groups. Day 14, standard and treated groups with dose $203 \mathrm{mg} / \mathrm{kg} \mathrm{BB}$ showed the statistically significant different $(\mathrm{p}<0.05)$ on blood glucose level compared to day 7 . While other treated group dose (90 and $135 \mathrm{mg} / \mathrm{kg} \mathrm{BW}$ ) showed the different blood glucose level on day 21. This was assumed that the dose $203 \mathrm{mg} / \mathrm{kg}$ BW gave the reducing blood glucose level faster than others. On this day, metformin and all three treated groups showed the reducing blood glucose level which were statistically significantly different to the control (Figure 4).

One day after treatment $\left(\mathrm{H}_{8}\right)$, standard group showed the highest reducing of blood glucose level compared to all other groups. On day 10 and 14, the highest percentage was shown by treated group with dose $90 \mathrm{mg} / \mathrm{kg} \mathrm{BW}$. While on day 21 , the highest reducing of blood glucose level was shown by treated group on dose of 135 and 203 $\mathrm{mg} / \mathrm{kg} \mathrm{BW}$ and have almost similar percentage. On day 28 , the highest percentage was shown by treated group on dose of $203 \mathrm{mg} / \mathrm{kg}$ BW. The percentage of reducing was dose dependent on this day. On day 1 after induction, treated group on dose $203 \mathrm{mg} / \mathrm{kg}$ BW showed the increase of blood glucose level compared to previous days. Single treatment of this dose did not show the decreasing of blood glucose level yet. The reducing activity increased after continuously treatment. At the end of treatment, on day 28 , the highest reducing was given by treated group with dose $203 \mathrm{mg} / \mathrm{kg}$ BW. Percentage of reducing blood glucose level on day 28 for standard, treated group with dose 90,135 , and $203 \mathrm{mg} / \mathrm{kg}$ BW were 33.05, 38.82, 41.79 , and $44.42 \%$ (Figure 5). This showed that the dose $203 \mathrm{mg} / \mathrm{kg}$ BW gave the optimal activity for reducing of blood glucose level.

For diabetes patients, it is often accompanied with the increase of serum triglyceride and cholesterol levels. This is caused by the mechanism of insulin in inhibition of lipase activity. Lipase break the lipids so called lipolysis which convert triglyceride into glycerol and fatty acids. 
The fatty acids are re-synthesized into triglyceride. Alloxan cause the defect of $\beta$-pancreas leading to insulin deficiency. As the compensation, lipolysis process is not inhibited leading to the accumulation of fatty acids. This cause the increase of re-synthesis of triglyceride and other lipoprotein including cholesterol. The highest blood glucose level related to the increase the triglyceride level. Through the biochemical process, glucose is converted into acetyl-CoA, which is converted further into fatty acids. Fatty acids from lipogenesis as well as from the food intake will be converted into triglyceride with the esterification.

Triglyceride (TG) and total cholesterol (CL) profile of mouse serum on day after induction with alloxan showed the increase of both for all groups. The increase of TG was ranging 143-185 mg/dL (Figure $6)$, while the increase of CL was ranging $137-178 \mathrm{mg} /$ dL (Figure 7). According the European Atherosclerosis Society, hypercholesterolemia and hypertriglyceridemia were shown by plasma CL and TG level above $>200$ $\mathrm{mg} / \mathrm{dL}$. The TG and CL of the animal model in this study were not classified as hypercholesterolemia and hypertriglyceridemia but have the risk of them. The TG and CL level showed in Figures 6 and 7 have almost similar profile, where the decrease of TG and CL level was shown by standard group which was statistically significant compare to the control $(\mathrm{p}<0.05)$. Treated groups on dose of 90 and $135 \mathrm{mg} / \mathrm{kg} \mathrm{BW}$ suppressed the increase of TG and CL level, while treated group on dose of 203 $\mathrm{mg} / \mathrm{kg} \mathrm{BW}$ did not show suppressed the decrease of TG and $\mathrm{C}$ level. The decrease activity on TG and CL was not shown by all three treated groups since there were not statistically different to standard group $(\mathrm{p}<0.05)$.

Metformin has the mechanism to increase activity of insulin in liver, muscle, and fat. Insulin has a role in metabolism of glucose and lipid. Insulin suppress the production of liver glucose, breaking of glycogen. In fat tissue, glucose is converted into free fatty acids and stored in a form of triglyceride. Insulin protect the breaking of triglyceride into free fatty acids, the form that can be transported into other tissues to be used. Insulin decrease free fatty acids in circulation and stimulant the storage of triglyceride and cholesterol and adipocyte (Setter \& Campbell 2000). Therefore, the metformin group showed the decrease of blood glucose level followed by the decrease of serum lipid level.

$P$. niruri has been studied its antidiabetes, hipolipidemia, and antioxidant activities on diabetic rat. Hypogycaemic effect is probably due to the insulin activity or stimulant of insulin effect (Bavarva 2007). Zerumbone is a main component of $Z$. americans that has been studied its antioxidant and hepatoprotective activities (Fakurazi 2008). The antioxidant activity could protect $\beta$-pancreatic cell damage from a reactive- oxygen species (ROS) which is radical specied produced by alloxan.

The sample extracts only showed the suppression of the increase of TG and CL level on dose of 90 and $135 \mathrm{mg} /$ $\mathrm{kg} \mathrm{BW}$. They did not show the decrease of TG and CL level. This is probably caused by the effect on the inhibition of resistance of TG and CL and did not influence toward the storage of TG and CL into adipocyte tissues, so that the TG and CL level in plasma was not changed after treatment.

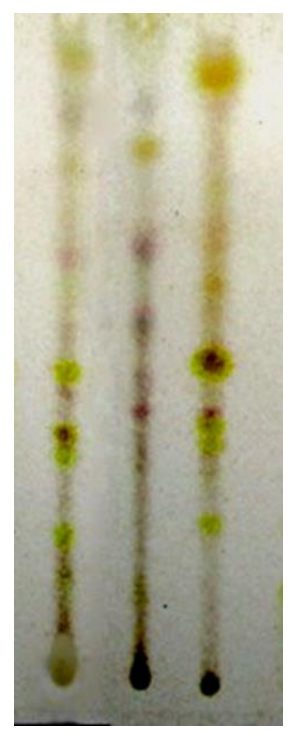

123

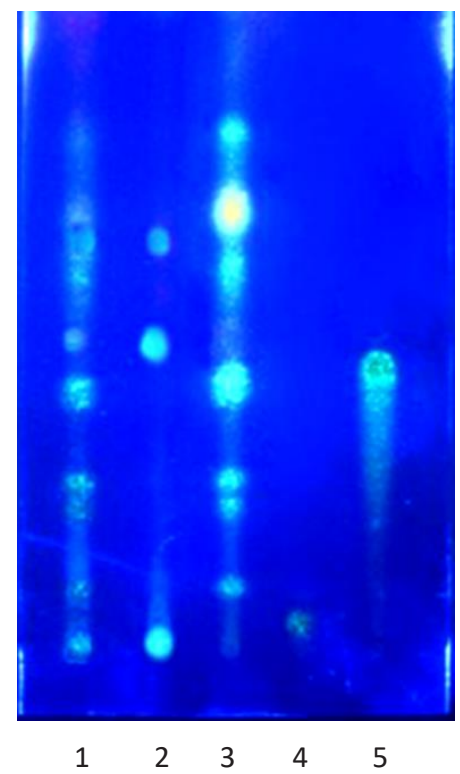

FIGURE 1. TLC chromatogram of sample extract (1), Phyllanthus niruri extract (2), Zingiber americans extract (3), quercetrin (4) and quercetin (5), visualization with spray reagent $\mathrm{H} 2 \mathrm{SO} 410 \%$ in methanol (left), citroborate (right), silica gel plate GF254, toluene-acetone (1:1) as mobile phase 


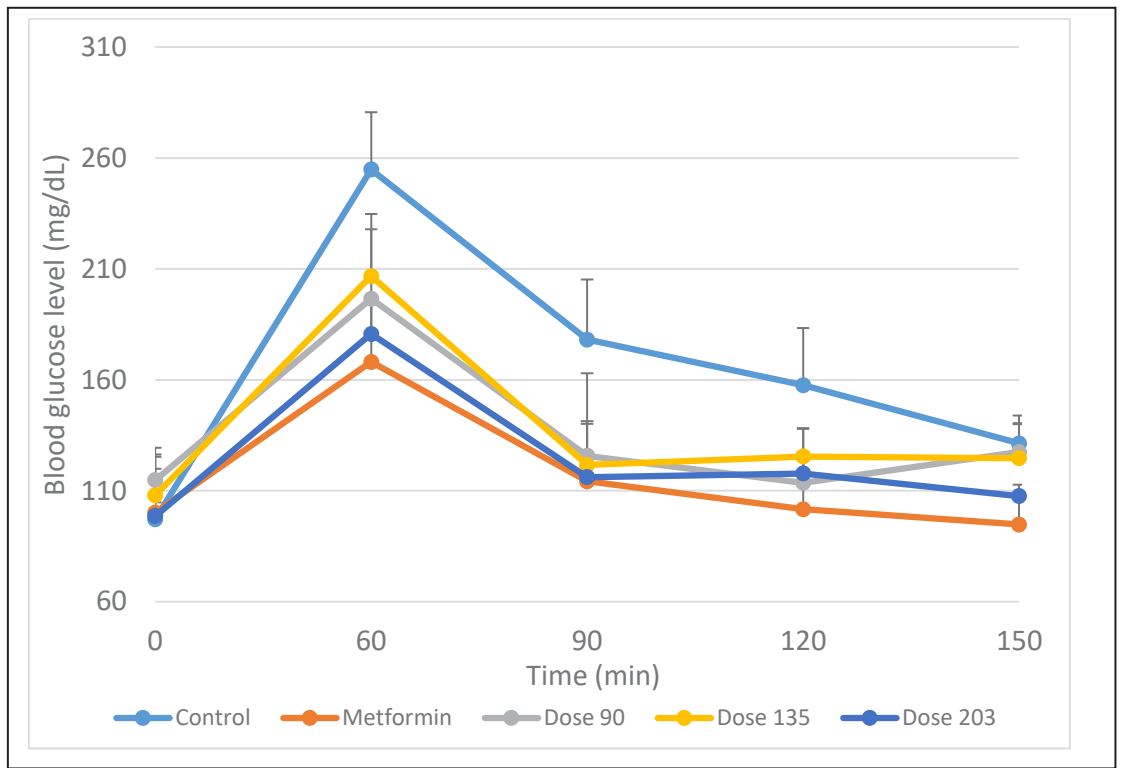

FIGURE 2. Blood glucose level profile using glucose tolerance method. Dose are in $\mathrm{mg} / \mathrm{kg}$ BW, Individual values expressed as means \pm standard deviation are averages of three independent experiments

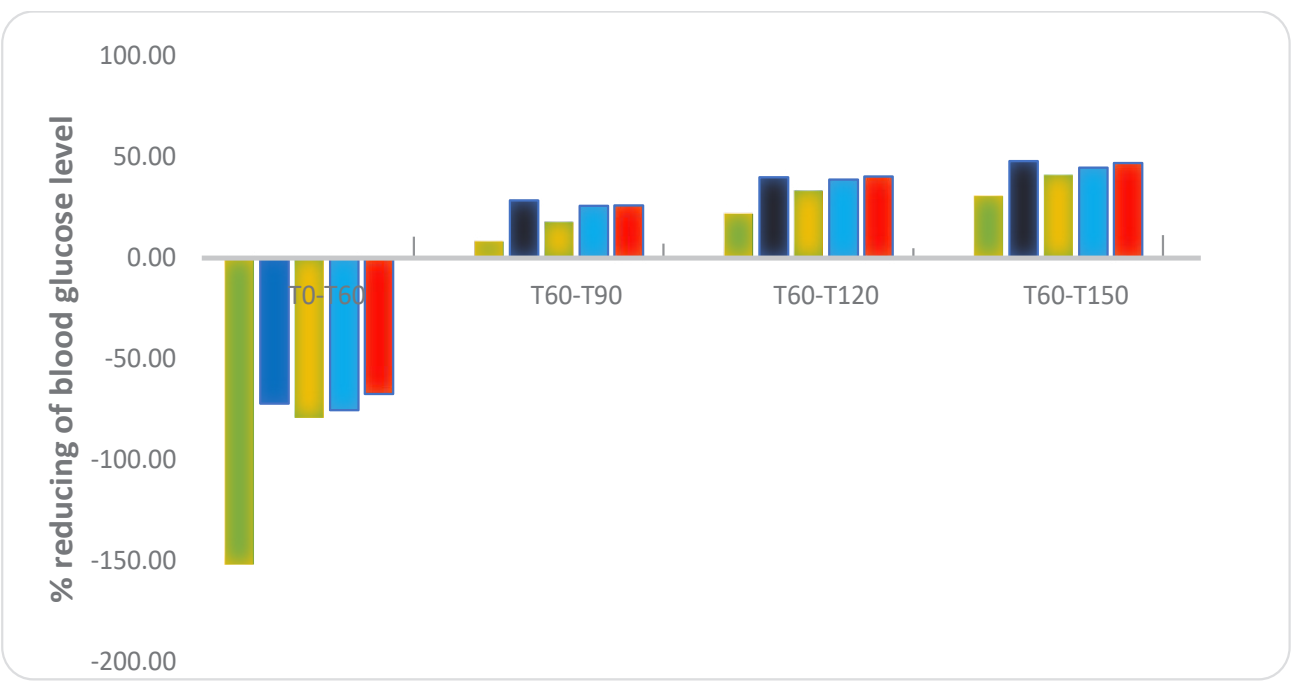

FIGURE 3. Percentage of the reducing of blood glucose level profile using glucose tolerance method. T60-T0 = Day 60 compare to day $0, \mathrm{~T} 60-\mathrm{T} 90, \mathrm{~T} 60-\mathrm{T} 120$, and T60-T150 $=$ day 90,120 and 150 respectively compare to day 60 . Individual values expressed as means \pm standard deviation are averages of three independent experiments 


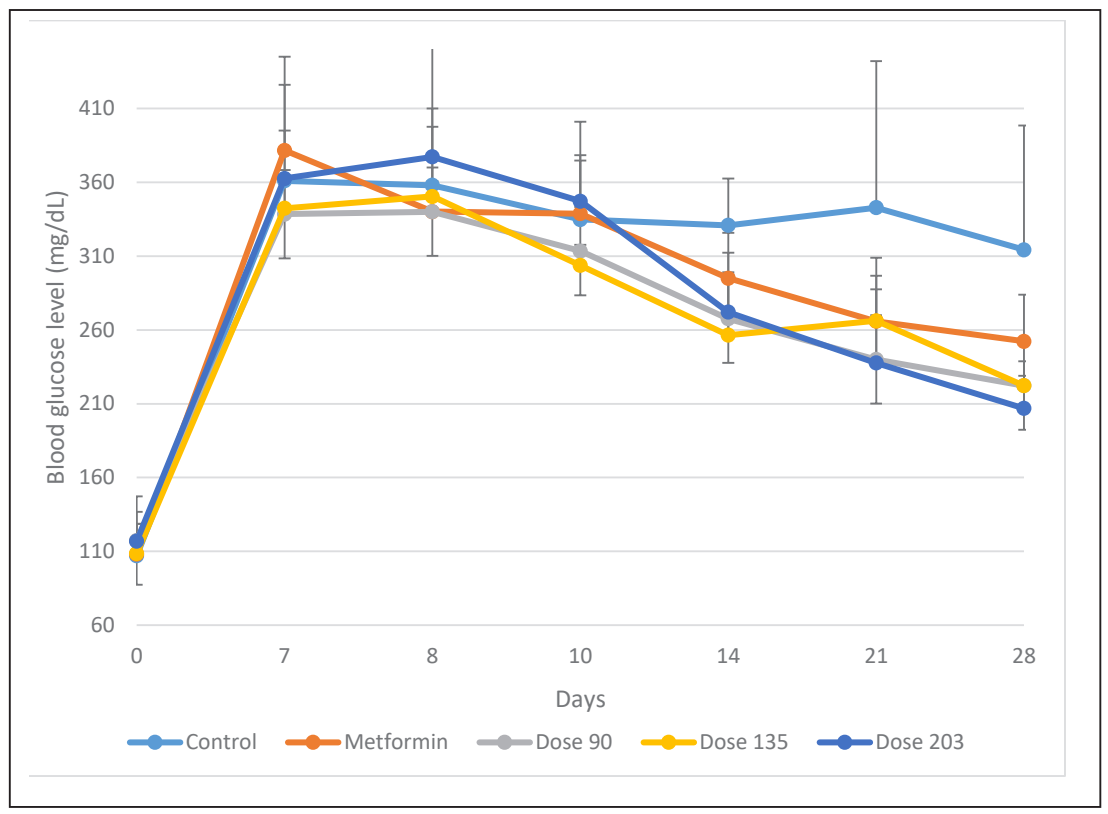

FIGURE 4. Blood glucose level profile using alloxan induced method. Dose are in $\mathrm{mg} / \mathrm{kgBW}$, Individual values expressed as means \pm standard deviation are averages of three independent experiments

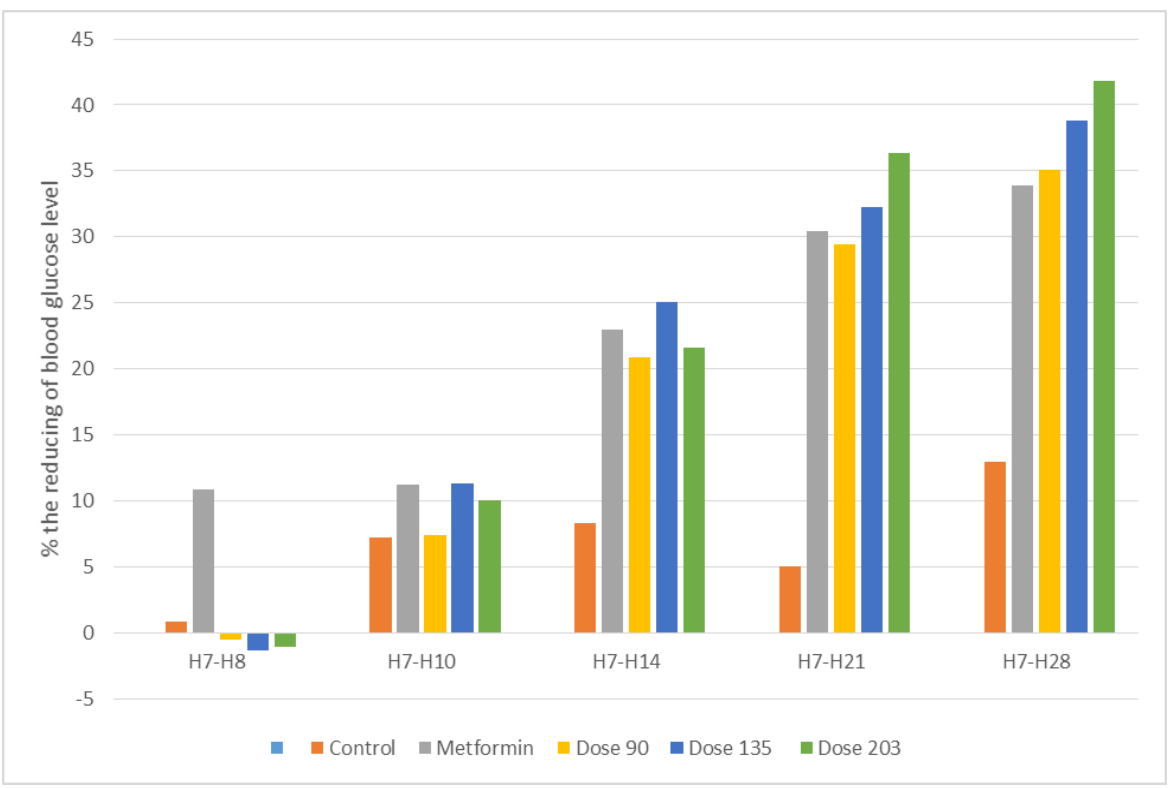

FIGURE 5. Percentage of the reducing of blood glucose level profile using alloxan induced method. Day 10, 14, 21 and 28 compare to day 7 . Individual values expressed as means \pm standard deviation are averages of three independent experiments 


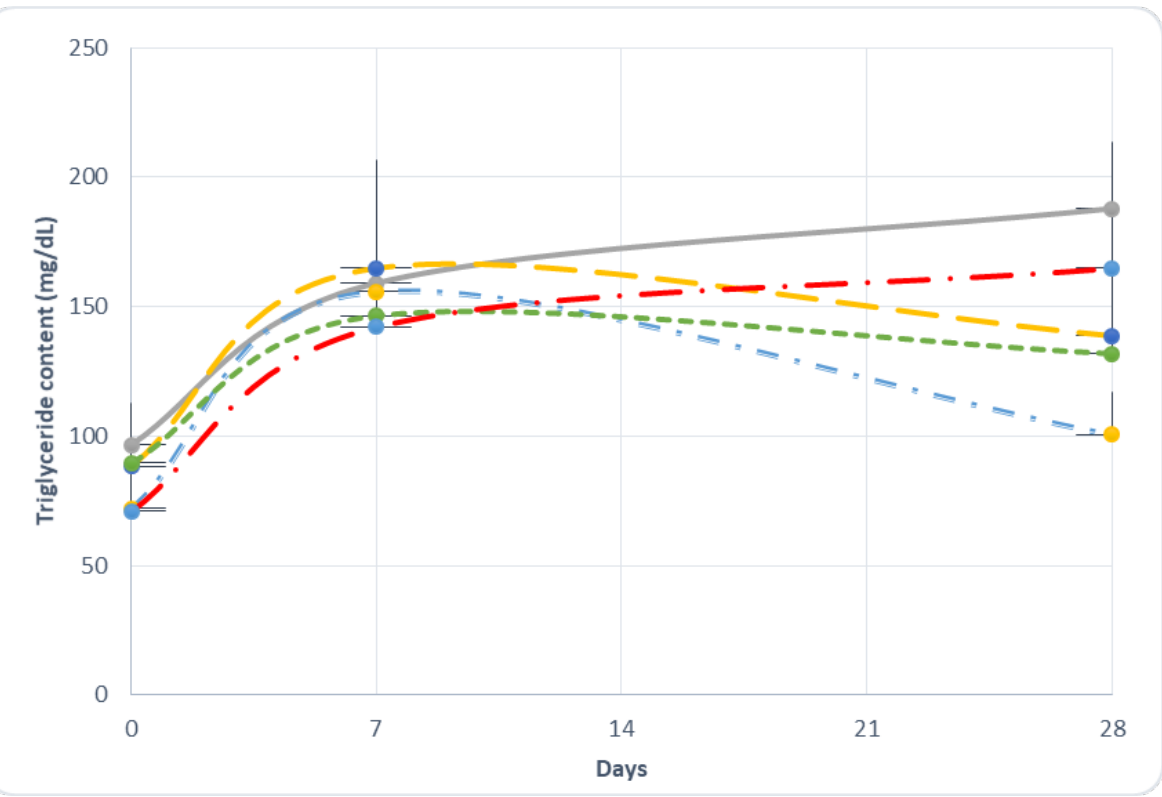

FIGURE 6. Triglyceride profile of all group using alloxan induced method. . Individual values expressed as means \pm standard deviation are averages of three

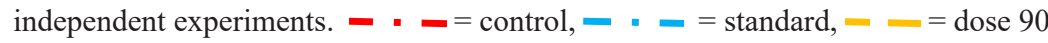
$\mathrm{mg} / \mathrm{kg} \mathrm{BW}, \boldsymbol{ー}=\boldsymbol{-}=\operatorname{dose} 135 \mathrm{mg} / \mathrm{kg}$ BW, $=$ dose $203 \mathrm{mg} / \mathrm{kg} \mathrm{BW}$

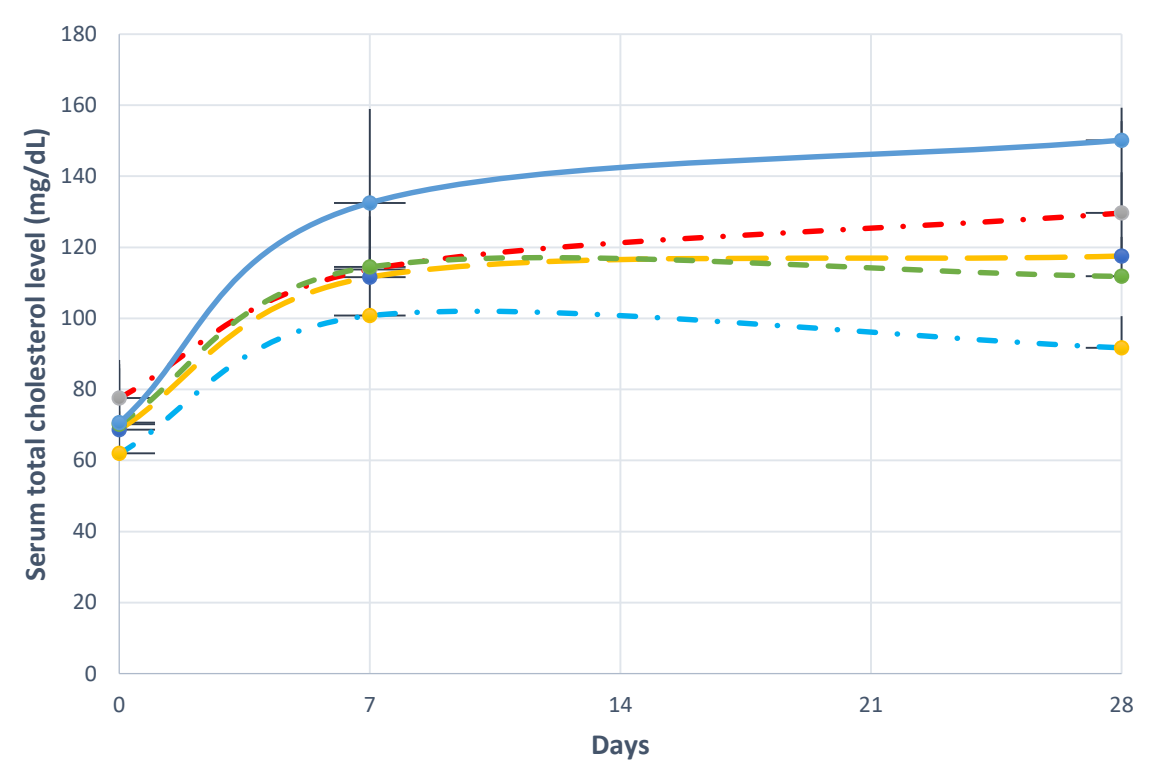

FIGURE 7. Total cholesterol profile of all group using alloxan induced method. Individual values expressed as means \pm standard deviation are averages of three independent experiments. $-=$ control, $-\cdots=$ standard, - $=$ dose $90 \mathrm{mg} / \mathrm{kg} \mathrm{BW}, \boldsymbol{=}=\boldsymbol{-}=\operatorname{dose} 135 \mathrm{mg} / \mathrm{kg} \mathrm{BW}$, - - $=$ dose $203 \mathrm{mg} / \mathrm{kg} \mathrm{BW}$ 


\section{CONCLUSION}

Herbal product which produced from medicinal plants Phyllanthus niruri and Zingiber americana contains flavonoid, phenol, and tannin with concentration of $0.15,0.16$, and $1.85 \%$, respectively. The extract with all doses showed the reducing of blood glucose level of animal model. The optimum reducing of glucose blood level was given by the extract dose $203 \mathrm{mg} / \mathrm{kg}$ BW. The reducing cholesterol and triglyceride level were given by extract dose 90 and $135 \mathrm{mg} / \mathrm{kg} \mathrm{BW}$.

\section{ACKNOWLEDGEMENTS}

The authors would like to acknowledge the Ministry of Research \& Technology and Higher Education for financial support through the community services program. Thanks for CV Dewa Honey, Depok, West Java, Indonesia who donate the herbal medicines product.

\section{REFERENCES}

Al-Amin, Z.M., Martha, T. \& Al-Qattan, K.K. 2006. Anti-diabetic and hypolipidemic properties of ginger (Zingiber officinale) in streptozotocin-induced diabetic rats. Brazilian Journal of Nutrition 96(4): 660-666.

Al Zarzour, R.H., Alshawsh, M.A., Asif, M., Al-Mansoub, M.A., Mohamed, Z., Ahmad, M., Majid, A.M.S.A., Asmawi, M.Z., Kaur, G., Al-dualimi, D.W. \& Yam, M.F. 2018. Adipocytokine regulation and antiangiogenic activity underlie the molecular mechanisms of therapeutic effects of Phyllanthus niruri against non-alcoholic fatty liver disease. Nutrients 10(8): 1057.

Al Zarzour, R.H., Ahmad, M., Asmawi, M.Z., Kaur, G., Saeed, M.A.A., Al-Mansoub, M.A., Saghir, S.A.M., Usman, N.S., Al-Dulaimi, D.W. \& Yam, N.F. 2017. Phyllanthus niruri standardized extract alleviates the progression of nonalcoholic fatty liver disease and decreases atherosclerotic risk in Sprague-Dawley rats. Nutrients 9(7): 766.

American Society of Health-System Pharmacists (AHFS). 2008. AHFS Drug Information. The American Society of Health-System Pharmacists Inc., Bethesda 3181-3185: 3234-3239.

Bavarva, J.H. \& Narasimhacharya, A.V.R.L. 2007. Comparative antidiabes, hypolipidemic, and antioxidant properties of Phyllanthus niruri in normal and diabetic rats. Pharmaceutical Biology 45(7): 569-574.

Calixto, J.B., Adair, R.S.S. \& Valdir, C.F. 1998. A review of the plants of the genus Phyllanthus: Their chemistry, pharmacology, and therapeutic potential. Medicinal Research \& Review 8(4): 225-258.

Chang, C., Yang, M. \& Wen, H. 2002. Estimation of total flavonoid content in propolis by two complementary colorimetric methods. Journal of Food Drug Analysis 10(3): 178-182.

Elfahmi, Woerdenbag, H.J. \& Kayser, O. 2014. Jamu: Indonesian traditional herbal medicine towards rational phytopharmacological use. Journal of Herbal Medicines 4(2): 51-73.
Fajardo, R.J., Karim, L., Calley, V.I. \& Bouxsein, M.L. 2014. A review of rodent models of type 2 diabetic skeletal fragility. Journal of Bone Mineral Research 29(5): 1025-1040.

Fakurazi, S., Hairuszah, I., Lip, J.M. \& Shanti, G. 2008. The effect of pretreatment of zerumbone on fatty liver following ethanol induced hepatotoxicity. Journal of Biological Science 8(8): 1348-1351.

Giribabu, N., Rao, P.V., Kumar, K.P., Muniandy, S., Rekha, S.S. \& Salleh, N. 2014. Aqueous extract of Phyllanthus niruri leaves displays in vitro antioxidant activity and prevents the elevation of oxidative stress in the kidney of streptozotocininduced diabetic male rats. Evidence-Based Complementary and Alternative Medicine 2014: 834815.

Indonesian Ministry of Health (IMH). 2008. Indonesian Herbal Pharmacopoea. First edition.

International Diabetes Federation. 2019. IDF Diabetes Atlas. 9th edition, International Diabetes Federation.

Jantan, I., Haque, M.A., Ilangkovan, M. \& Arshad, L. 2019. An insight into the modulatory effects and mechanisms of action of Phyllanthus species and their bioactive metabolites on the immune system. Frontiers in Pharmacology 10: 878.

Júnior, R.F.A., Soares, L.A.L., Porto, C.R.C., De Aquino, R.G.F., Guedes, H.G., Petrovick, P.R., De Souza, T.P., De Araújo, A.A. \& Guerra, G.C.B. 2012. Growth inhibitory effects of Phyllanthus niruri extracts in combination with cisplatin on cancer cell lines. World Journal of Gastroenterology 18(31): 4162-4168.

Mostofa, R., Ahmed, S., Begum, M.M., Rahman, M.S., Begum, T., Ahmed, S.U., Tuhin, R.H., Das, M., Hossain, A., Sharma, M. \& Begum, R. 2017. Evaluation of antiinflammatory and gastric anti-ulcer activity of Phyllanthus niruri L. (Euphorbiaceae) leaves in experimental rats. BMC Complementary and Alternative Medicine 17(1): 267.

Nisar, M.F., He, J., Ahmed, A., Yang, Y., Li, M. \& Wan, C. 2018. Chemical components and biological activities of the genus Phyllanthus: A review of the recent literature. Molecules 23(10): 2567.

Nwanjo, H.U., Oze, G. \& Okafor, M.C. 2007. Protective role of Phyllanthus niruri extract on serum lipid profiles and oxidative stress in hepatocytes of diabetic rats. African Journal of Biotechnology 6(15): 1744-1749.

Sarin, B., Verma, N., Martín, J.P. \& Mohanty, A. 2014. An overview of important ethnomedicinal herbs of Phyllanthus species: Present status and future prospects. The Scientific World Journal 2014: Article ID. 839172.

Setter, S.M. \& Campbell, R.K. 2000. Diabetes, in Textbook of Therapeutic Drug and Disease Management, 7 th ed., edited by Herfindl, E.T. \& Gourley, D.R. Lippincot Williams \& Wilkins, Philadelphia. pp. 377-405.

Shan, J.J., Min, Y. \& Jin-Wei, R. 2006. Anti-diabetic and hypolipidemic effects of aqueous extract from the flower Inula japonica in alloxan-induced mice. Biological \& Pharmaceutical Bulletin 29(3): 455-459.

Sukari, M.A., Sharif, N.W.M. \& Yapi, A.L.C. 2008. Chemical constituents variations of essential oils from rhizomes of four Zingiberaceae species. The Malaysian Journal of Analytical Sciences 12(3): 638-644.

Szkudelski, T. 2000. The mechanism of alloxan and streptozotocin action in B Cells of the rat pancreas. Physiology Research 50(6): 537-546. 
Tang, Y.Q., Jaganath, I., Manikam, R. \& Sekaran, S.D. 2013. Phyllanthus suppresses prostate cancer cell, PC3 , proliferation and induces apoptosis through multiple signalling pathways (MAPKs, PI3K/Akt, NFkB, and Hypoxia). Evidence-Based Complementary and Alternative Medicine 2013: Article ID. 60958.

World Health Organization (WHO). 2019. Classification of Diabetes Mellitus 2019. World Health Organization.

Wild, S., Roglic, G. \& Green, A. 2004. Global prevalence of diabetes: Estimates for the year 2000 and projections for 2030. Diabetes Care 27(5): 1047-1051.

Zheng, Z.Z., Chen, L.H., Liu, S.S., Deng, Y., Zheng, G.H., Gu, Y. \& Ming, Y.L. 2016. Bioguided fraction and isolation of the antitumor components, from Phyllanthus niruri L. BioMed. Research International 2016: Article ID. 9729275.

Elfahmi*, I Ketut Adnyana \&Ika Fitria

School of Pharmacy

Bandung Institute of Technology

Bandung

Indonesia
Elfahmi*

University Centre of Excellence, Nutraceutical Bioscience and Biotechnology Research Center Bandung Institute of Technology

Bandung

Indonesia

Taufik Taufikurahman

School of Life Sciences and Technology

Bandung Institute of Technology

Bandung

Indonesia

*Corresponding author; email: elfahmi@fa.itb.ac.ic

Received: 16 January 2020

Accepted: 7 May 2020 